\title{
ANALYSIS OF THE ROLE OF FINTECH AND FINANCIAL LITERATION ON BUSINESS PLAYERS IN CILEDUG TANGERANG REGION
}

\author{
Triyani Budyastuti \\ Mercu Buana University \\ Jakarta, Indonesia
}

Article DOI: $\underline{\text { https://doi.org/10.36713/epra4792 }}$

\begin{abstract}
This study aims to analyze the role of fintech and financial literacy in business operators in the Ciledug area of Tangerang. In this study, researchers took a random sample of business people who are in the Ciledug Village, Tangerang. Analysis of the data used in this study is to use data reduction in the presentation of thendata and the last is a conclusion. The results of this study are, in general, informants do not understand what is fintech, they only know online payments such as ovo, funds, paypal, etc. They do not know that online payment is included in fintech. Business owners also dislike borrowing money for venture capital from fintech because of its large interest. The owner generally prefers to make a personal loan or through banking.

For financial literacy, they have more or less understood that financial management is important. And some owners have prepared their future well. Preparing an education fund for children, having an emergency fund, having self and family health insurance are their capital for the future.

KEYWORDS: Fintech, Financial Literacy, Business Players
\end{abstract}

\section{BACKGROUND}

Technology is developing rapidly, not only in Indonesia but the world is also experiencing technological developments that are changing significantly every time. This can occur because the technology is growing rapidly every day and has entered in various sectors, one of which is the financial sector. An example is fintech (Financial technology) which is a technology to support financial services.

The development of fintech has led to many innovative applications in financial services, such as payment instruments, loan instruments and others that are gaining in popularity in this digital age.

Today many people are turning to fintech because people now want everything to run quickly and easily, without any limitations. OJK functions as a supervisor of the government to regulate the financial services sector, especially in the development of fintech. OJK supervises p2plending fintech, Crowdfunding, Digital Banking Fintech in the capital market, Insurtech, online financing, data security and consumer protection. Micro, Small and Medium Enterprises The emergence of fintech innovation provides a breath of fresh air for MSME businesses. Fintech helps business people more easily get access to financial products and increase financial literacy.

Business people can use fintech as a way to finance their companies. The role of fintech is not only limited to business capital financing, but there are also those that penetrate into various aspects such as digital payment services and financial regulators. The presence of technology-based financial fintech services 
in Indonesia has become a necessity in line with the development of information and communication technology (Wibowo, 2016).

Micro, Small and Medium Enterprises (MSMEs) have a big role to play in increasing economic development in Indonesia, economic growth and opening up new jobs. At present, the number of MSMEs in Indonesia continues to increase and develop in various sectors. With the improvement and development of MSMEs, it is expected to be able to increase Gross Domestic Product (GDP) and absorb more new workers to reduce unemployment and poverty. Because the number of MSMEs that have sprung up makes competition tighter. Especially after the enactment of the ASEAN Economic Community (AEC), which makes the MSMEs must produce new innovations so that they can meet market demands and make Indonesia a market leader in their own countries and in ASEAN.

The emergence of fintech innovation provides a breath of fresh air for MSME businesses. Fintech helps business people more easily get access to financial products and increase financial literacy. Business people can use fintech as a way to finance their companies. Based on research on the role of fintech on MSMEs the results of research from Irma, Inayah, Bella (2018) stated that the presence of a number of fintechs contributed to the development of MSMEs. The role of fintech is not only limited to financing venture capital but there are also those that penetrate into various aspects such as digital payment services and financial regulators.

Micro, Small and Medium Enterprises (MSMEs) in Ciledug, Tangerang, are currently developing, but MSME businesses are still comfortable using cash in their transactions. Funding for the development of MSME is also a problem that is often faced by SMEs. Customers of MSME products also want to make transactions easier.

\section{LITERATURE REVIEW Financial Technology (Fintech)}

Financial technology or financial technology or what is commonly referred to as fintech, is defined as technological innovation in financial services that can produce business models, applications, processes or products with material effects related to the provision of financial services (Financial Stability Board, 2017). Fintech also helps people to more easily get access to financial products and financial literacy (Finansialku.com, 2018. The financial technology industry (fintech) is one of the methods of financial services that is starting to rise in the digital era like today.

Digital payments are one of the sectors in the most fintech industry in Indonesia. So that the government and the public hope that digital payments can encourage the number of people who have access to financial services. The Financial Services Authority (OJK) notes there are around 63 financial technology companies that have been registered until June 2018 and in August there were about 64 companies registered with 6 listed companies and 5 there were cancellations of registration (OJK, 2018).

There are several types of fintech classifications, namely:

1. Crowdfunding and peer to peer lending

Crowdfunding is a business unit funding technique or business project that involves humans extensively (kemenkeu.go.id, 2017). Peer to peer lending ( $\mathrm{p} 2 \mathrm{plending}$ ) is a practice or method of giving money to individuals or businesses and vice versa, applying for loans to lenders that connect lenders with borrowers or investors online (Koinwork.com, 2018).

2. Market Aggregator

Market aggregator is collecting and managing data that can be used by consumers to help decision making (CNB Indonesia, 2018).

3. Risk and Investment Management

Risk and investment management or commonly referred to as risk and investment management in financial technology is used as planning in digital form.

4. Payment, Settlement and Clearing

Payment, settlement and clearing are the fintech sectors with payment system services both organized by the banking industry or Bank Indonesia institutions (CNBC Indonesia, 2018).

\section{Financial Literacy}

According to Manurung (2009: 24) financial literacy is a set of knowledge and skills that enable a person to make effective decisions with all their financial resources.

According to the Financial Services Authority (OJK), Financial Literacy is knowledge, skills and beliefs, which influence attitudes and behaviors to improve the quality of decision making and financial management in order to prosper OJK states that the important mission of the financial literacy program is to do so that the Indonesian people can manage finances smartly so that education is needed in the field of finance, so that low knowledge about the financial industry can be overcome and the public is not easily 
ISSN (Online): 2455-3662

EPRA International Journal of Multidisciplinary Research (IJMR) - Peer Reviewed Journal Volume: 6 | Issue: 7 | July 2020 || Journal DOI: 10.36713/epra2013 || SJIF Impact Factor: 7.032 ||ISI Value: 1.188

fooled into investment products that offer high returns in the short term without considering the risks. In supporting economic functions, financial literacy is needed because with the large transactions that can be created it will make the wheels of the economy perfect.

Financial literacy has a long-term goal for all classes of society, namely increasing the literacy of a person who was previously less literate or not literate to be well literate and increasing the number of users of financial products and services. In supporting economic functions, financial literacy is needed because with the large transactions that can be created it will make the wheels of the economy perfect.

\section{Micro, Small and Medium Enterprises (MSMEs)}

Based on Law No. 20/2008, the meaning of Micro, Small and Medium Enterprises (MSMEs) is

1. Micro business is productive business owned by individuals and / or individual business entities that meet the criteria for micro business as regulated in this law.

2. Small business is a productive economic business that stands alone, which is carried out by individuals or business entities that are not subsidiaries or non-branch companies that are owned, controlled, or become either directly or indirectly part of medium-sized businesses or large businesses that fulfill small business criteria as referred to in this law.

3. Medium-scale business is a productive economic business that stands alone, which is carried out by an individual or business entity that is not a subsidiary or branch of a company that is owned, controlled, or becomes a part either directly or indirectly with a small business or large business with an amount of wealth net or annual sales results as provided for in this law.

According to Abduh, Thamrin (2018: 12) small and medium enterprises have a strategic role in the development of the national economy, and the absorption of labor also acts as a distribution of business results. MSME is a sector that can reduce the level of economic and social inequality, foster a family system and cooperation and in the economic field can increase purchasing power of consumers in the country (Wulansari et al, 2017).
Table 2.1 MSME Criteria

\begin{tabular}{|c|c|c|c|}
\hline No. & $\begin{array}{l}\text { Business } \\
\text { Criteria }\end{array}$ & Asset & $\begin{array}{l}\text { Criteria } \\
\text { Turnover }\end{array}$ \\
\hline 1 & $\begin{array}{c}\text { Micro } \\
\text { business }\end{array}$ & $\underset{\text { million }}{\operatorname{maximum}} 50$ & $\begin{array}{l}\text { maximum } \\
300 \text { million }\end{array}$ \\
\hline 2 & $\begin{array}{c}\text { Small } \\
\text { Business }\end{array}$ & $\begin{array}{c}>50 \text { million - } \\
500 \text { million }\end{array}$ & $\begin{array}{c}>300 \\
\text { million - } 2.5 \\
\text { billion }\end{array}$ \\
\hline 3 & $\begin{array}{c}\text { Medium } \\
\text { Enterprises }\end{array}$ & $\begin{array}{l}>500 \text { million } \\
-10 \text { billion }\end{array}$ & $\begin{array}{c}>2.5 \text { billion - } \\
50 \text { billion }\end{array}$ \\
\hline
\end{tabular}

Source: OJK

\section{RESEARCH METHOD Research Methods}

The type of research used is qualitative research with descriptive content analysis. Qualitative research (qualitative research) includes the interpretation of interpretative techniques with understanding, not the frequency of phenomena that often or rarely occur naturally in the social world (Cooper and Schindler, 2017: 170). Descriptive content analysis or descriptive content analysis is content analysis that is intended to describe in detail a message or a particular text. Content analysis is only for description, describing the characteristic aspects of a message (Eriyanto, 2017: 47).

\section{Data Collection Methods}

The method used by researchers is: Interview

According to Sugiyono (2015, p. 231) Interviews are data collection techniques if the researcher wants to conduct a preliminary study to find problems that need to be investigated, but also if the researcher wants to know things from the respondents in more depth.

Interview is a process of communication or interaction to collect information by question and answer between researchers and informants or research subjects. With the progress of information technology as it is today, interviews can be done without face to face, namely through telecommunications media. In essence the interview is an activity to obtain in-depth information about an issue or theme raised in research. Or, it is a process of proving the information or information that has been obtained through other techniques before.

Because it is a verification process, interview results may be appropriate or different from information that has been obtained previously. 
In order for an interview to be effective, there are several stages that must be passed, namely; 1). Introduce yourself, 2). Explain the purpose of arrival, 3). Explain the interview material, and 4). Asking questions (Jonah, 2010: 358).

\section{Data analysis method}

In qualitative research, data is obtained from a variety of sources, using a variety of data collection techniques (triangulation), and carried out continuously until the data is saturated. Qualitative data analysis is inductive in nature, which is an analysis based on the data obtained, then developed certain patterns of relationships or become hypotheses.

Data analysis in qualitative research carried out since before entering the field, while in the field and after completion in the field.

In this case Nasution (1988) in (Sugiyono, 2015, p. 245) states "The analysis has begun since formulating and explaining the problem, before plunging into the field and continuing until writing research results. But in qualitative research, data analysis is more focused during the field process together with data collection. "

Analysis of data data is an important step in research, because it can give meaning to the data collected by researchers. Data obtained and collected from respondents through the results of observations, interviews, literature studies and documentation in the field to be further described in the form of reports.

Data analysis in this research was carried out through three activities occur simultaneously namely data reduction, data presentation, and withdrawal the conclusion or verification of Miles and Huberman (1992) in Sugiyono (2015, p. 246). Qualitative data analysis is an ongoing effort, repeatedly and continuously. Problems with data reduction, data presentation, and withdrawal the conclusion is a series of interrelated analysis of activities follow up.

\section{RESULTS AND DISCUSSION}

The role of fintech in business actors In this study, researchers took random speakers who were in Ciledug Tangerang.

a. PO. Sumber Alam is a transportation business that has been running for approximately 20 (twenty) years. The owner does not understand the types of fintech available, the owner only knows fintech as a means of payment. Sumber Alam has been reducing its use of paper in a number of years. The transaction that was originally started with a booking will then be replaced with a ticket when the current departure no longer exists. Current transactions of natural resources are already using the application, so potential passengers can buy online. This is in line with research conducted by EN Sugiarti (2019) which states that transactions using applications can minimize errors in transactions, environmentally friendly because it can reduce the amount of paper. In PO. Sumber Alam payment transactions still use cash or transfer. The use of digital paymet is still in the owner's plan.

b. The second guest speaker was Khanza Mandiri. Khanza Mandiri started its business about 10 years ago. Khanza Mandiri is engaged in the Payment and grocery business. The owner gives an explanation of understanding of fintech, the owner in general only knows that fintech is a means of payment such as OVO, funds, etc. Using their own capital and for financial arrangements Khanza Mandiri still uses manual bookkeeping. The owner is interested in using fintech in his payment.

c. The third speaker was Mrs. Puji who traded hodgepodge on Ciledug Raya street for about 4 years ago. Ms. Puji acknowledged that of the several types of fintech available, Ms. Puji only knew about payment fintech where she was familiar with payment instruments such as OVO, Gopay, etc. When researchers provide understanding that fintech is not only a means of payment, including online loans, he is reluctant to do so because of the large interest. He is interested in making non-cash payments but is constrained by the submission process.

d. The next guest speaker was Tantowi Chicken Noodle. The owner started his business 8 years ago. Starting from the roadside hangout, now the owner is able to rent a place that is quite permanent. The owner is aware of the rapid technological owner must participate to compensate. At present the owner has proposed to the provider to be able to receive non-cash payments such as OVO, but has not yet received approval from Fintech's Patah.

\section{The Role of Financial Literacy in Business Actors}

a. PO owner. Sumber Ciledug does not have detailed financial records. However, the owner always prepares good funds to prepare for the future, children's education to university level, has insurance for themselves and their families. The owner also realizes the importance of financial 
management, because according to him if the financial is not managed it will disrupt cash flow. In addition the owner also knows the services that exist in the bank. The owner will trust banking services in managing his finances.

b. The owner of Khanza Mandiri has a financial log for his business. The owner has plans to enlarge his business in the future. The owner also has an emergency fund as well as savings for the future. In addition, the owner has also prepared health insurance for himself and his family, as well as education funds for children to college. The owner understands that finance needs to be managed so that the peg is not bigger than the pole. Most owners know the types of services that are available at the bank. The owner chooses savings as savings and believes in banking services. The owner has so far not been familiar with mutual funds to invest.

c. Mrs. Puji does not have a financial record for her business. The owner has plans to enlarge his business in the future. The owner does not have an emergency fund and has not planned an education fund for children to college. However, the owner has health insurance for himself and his family. The owner realizes that finance needs to be managed to find out the entry and exit of money and also to know the profit or loss. The owner also knows the types of banking services available. The owner chooses savings at the bank and believes in charging services. The owner does not know the types of investments and is not familiar with investments such as mutual funds.

d. The owner of Mie tantowi chicken has a business financial record book. Similar to other business owners, Mia Tantowi also intends to enlarge her business in the future. The owner has also prepared and educated his children. However, the owner does not yet have health insurance for himself and his family. The owner prefers savings as savings in the bank, because the owner believes in his security. The owner does not know the types of investments available, the owner knows investment is only limited to gold.

\section{DISCUSSION}

\section{a. Financial Technology}

\section{Length of Effort}

There are business people in this research who have been doing it for decades. Business back and forth will always happen, and therefore innovation and expansion of business actors is needed to stay afloat in the business world, given the rapid development of technology today, so that businesses are expected to be able to take part in utilizing current technology which is completely online.

2. Business actors' knowledge of fintech

Fintech is increasingly growing to make business peoplemust be able to follow its development. Business people don't just have to follow but business players are expected to be more selective in choosing fintech because many finteches have not been registered with OJK. Knowledge business people about fintech are still limited, they don't know much about their roles from fintech, many business operators know the role of fintech only as payment.

3. The application of fintech to business actors Actors have actually realized the benefits of using fintech, but the owner also considers consumer interests. Like Sumber Alam, where the majority of consumers are more interested in using cash because of the age factor, where there are still many consumers who do not like non-cash payments. This is in line with research conducted by F Mahliza (2019) which states that the owner's characteristics do not affect the implementation of e-commerce.

From the four sources the overall reception received well with the existence of fintech because fintech can simplify transactions. Fintech too provide a lot of benefits for business people as well as more profits obtained from business actors. But of all the roles of fintech, the guest speaker is in this research does not yet fully know what the role of fintech is because lack of socialization about fintech to business actors. The guest speaker said in venture capital financing still chooses banking because banks already trusted and there are legal institutions that govern. The four speakers from this study said that in financing many businesses use their own capital and when in business need capital, businesses still choose banking over fintech. The speakers said that with their own capital you should be able to expand their business. The emergence of fintech provides opportunities for para business actors are creative in using financial technology services with various roles from fintech ranging from payments, financing, investment, to planning finance. The speakers in this study use the role of fintech as payment (e-payment) and financial managers because of little interest from customers little by little using financial technology because it gives the impression which is easy to use. This makes para profit 
business actors have increased so that the financial literacy of business actors has also increased.

\section{Financial Literacy}

Basically, the four informants understood and understood that business finance needs to be managed well, but some of the speakers had not done financial records properly. This is in line with research conducted by Juma Buhimila Mabula (2018) suggested that there is positive relationship between financial literacy and firm practice of record keeping. The PLS structural path coefficient in this it is not significant. Suggesting that there is no direct relationship between financial literacy and the practice of book keeping. Though it is hard to draw a conclusion on insignificant results speculation can be on factors like the managers" level of education and factors for financial information flow constructs may mediate or moderate the relationship between financial literacy and firm book keeping practice. However, overall business owners have the same plan for their business, which is to enlarge their business. Some owners already have education funds for children to college as stated by the owner of Sumber Alam and Khanza Mandiri. For types of deposits, the owner generally knows about banking services and prefers savings. Owners believe their money is safe if it is deposited in a bank. Some owners have also prepared an emergency fund. Some owners also have health insurance for themselves and their families, because they realize the importance of health.

\section{REFERENCES}

1. Abduh. Thamrin, 2018, "Strategi Internasionalisasi UMKM", Sah Media

2. Azwar. Saifuddin, 2005, "Sikap Manusia Teori dan Pengukurannya”, Yogyakarta: Pustaka Pelajar

3. CNBC Indonesia, 2018, "Ini Dia Empat Jenis Fintech di Indonesia", https://www.cnbcindonesia.com/fintech/201801101 45800-37-1126/ini-dia-empatjenis-fintech-diindonesial, Diakses 13-10-2018

4. Cooper. Donald dan Schindler, 2017, "Metode Penelitian Bisnis" Edisi Dua Belas Buku Satu. Jakarta: Salemba Empat

5. EN Sugiarti. 2019. Peran Fintech dalam Meningkatkan Literasi Keuangan Pada Usaha Mikro Kecil Menengah di Malang . Jurnal Ilmiah Riset Akuntansi Vol 8 No. 04.

6. F Mahliza. 2019. The Influence Of E-Commerce Adoption Using Social Media Towards Business Performance Of Micro Enterprises. International Journal of Business, Economics and Law Vol 8 issue 5 (April)

\section{CONCLUSIONS AND SUGGESTIONS 1. Conclusions}

From the above discussion conclusions can be drawn:

a. In general, informants did not understand what fintech was, they knew only online payments such as ovo, funds, paypal, etc. They do not know that online payment is included in fintech. Business owners also dislike borrowing money for venture capital from fintech because of its large interest. The owner generally prefers to make a personal loan or through banking.

b. For financial literacy, they have more or less understood that financial management is important. And some owners have prepared their future well. Preparing an education fund for children, having an emergency fund, having self and family health insurance are their capital for the future.

\section{Suggestions}

Suggestions given by researchers based on the results of research that has been done is as follows:

a. It is hoped that fintech parties can provide socialization and education for business actors, so that business actors can utilize fintech for business progress.

b. Increase the number of sources so that interview results can be more accurate.

7. Finansialku.com, 2018, "Definisi Fintech”, https://www.finansialku.com/definisi-fintechadalah/. Diakses 13-04-2020

8. FSB, 2017, "Financial Stability Implications from Fintech", content/uploads/R270617.pdf/. Diakses 15-04-2020

9. Irma Muzdalifah. Inayah Aulia dan Bella Gita, 2018, "Peran Fintech dalam Meningkatkan Keuangan Inklusif pada UMKM di Indonesia" Jurnal Masharif-Syariah Vol. 3, No. 1.Universitas Muhammadiyah Surabaya

10. Juma Buhimila Mabula \& Han Dong Ping. 2018. Use of Technology and Financial Literacy on SMEs Practices and Performance in Developing Economies. International Journal of Advanced Computer Science and Applications, Vol. 9, No. 6, 2018.

11. Koinwork.com, 2018, "Semua yang Perlu Anda Ketahui Tentang Peer to Peer Lending (P2P Lending ".https://koinworks.com/blog/ketahuitentang-peer-peer-lending/. Diakses 13-10-2018

12. Luckandi. Diardo, 2018, "Analisis Transaksi Pembayaran Menggunakan Fintech Pada 
ISSN (Online): 2455-3662

EPRA International Journal of Multidisciplinary Research (IJMR) - Peer Reviewed Journal

Volume: 6 | Issue: 7 | July 2020 || Journal DOI: 10.36713/epra2013 || SJIF Impact Factor: 7.032 ||ISI Value: 1.188

UMKM di Indonesia: Pendekatan Adaptive Structuration Theory", Tesis. Universitas Islam Indonesia

13. Manurung. Adler $H$ dan Rizky. Lutfi T, 2009. "Succesful Financial Planner: A Complete Guide”, Jakarta: Grasindo

14. Otoritas Jasa Keuangan, 2018, "Penyelenggara Fintech yang Terdaftar di OJK per Agustus 2018".https://www.ojk.go.id/id/berita-dankegiatan/publikasi/Pages/Penyelenggara FintechTerdaftar-di-OJK-per-Agustus-2018.aspx/. Diakses 12-10-2018

15. Siamsyah. Dhoni, 2016, "Mendorong Crowdfunding untuk Peningkatan Investasi di Indonesia"http://www.kemenkeu.go.id/. Diakses 06-07-2019
16. Undang -Undang Nomor 20 Tahun 2008 tentang Usaha Mikro, Kecil, dan Menengah

17. Wibowo. Budi, 2016, "Analisa Regulasi Fintech dalam Membangun Perekonomian di Indonesia" Program Magister Teknik Elektro. Universitas Mercu Buana

18. Wulansari, Wahyu dan Kurniawan, 2017, "Akselerasi Pertumbuhan Ekonomi Melalui Sinergi UMKM dan Good Governance di Indonesia", Prosiding Seminar Nasional dan Call For Paper Ekonomi dan Bisnis. Universitas Jember

19. Yunus, Hadi Sabari. 2010. Metodologi Penelitian Wilayah Kontemporer. Yogyakarta: Pustaka Pelajar. 